\title{
Investigating the Effect of Corporate Diversification on the Value of Companies in Tehran Stock Exchange
}

\author{
Hoshang Amiri ${ }^{1}$, Samare Sawari ${ }^{2,}$ \& Mahdi Bazrafshan ${ }^{2}$ \\ ${ }^{1}$ Department of Accounting, Abadan Branch, Islamic Azad University, Abadan, Iran \\ ${ }^{2}$ Department of Accounting, Khorramshahr- Persian Gulf International Branch, Islamic Azad University, \\ Khorramshahr, Iran \\ *Correspondence: Department of Accounting, Khorramshahr- Persian Gulf International Branch, Islamic Azad \\ University, Khorramshahr, Iran. E-mail: samira_savari60@yahoo.com
}

Received: March 26, $2018 \quad$ Accepted: April 11, $2018 \quad$ Online Published: April 17, 2018

doi:10.5430/mos.v5n2p27 URL: https://doi.org/10.5430/mos.v5n2p27

\begin{abstract}
This research examined effect of corporate diversification on the firm's value in companies listed in Tehran Stock Exchange during the years 2006 till 2013. To answer the question posed one hypothesis. The hypothesis examined the relationship between the company's diversification and growth opportunities. Dependent variable of the study is company's value. Enterprise value has been calculated by natural logarithm of the market value per share of the company's expected value. The independent variable of this research is diversification that was calculated by entropy index. To select the sample size of the study population the systematic elimination method is used, and finally 263 companies that were consistent with the research, was selected. To test the hypothesis of Panel data is used. The results show a significant positive impact between diversification and company's firm value.
\end{abstract}

Keywords: diversification, panel data, firm value, entropy index

\section{Introduction}

Firm's diversification and its impact on the value of a company is a controversial old issue in financial research. Fast changing conditions are a feature of the today's world issues, and in this situation, competition has gained momentum. Therefore, economic, and in particular manufacturing units, should transform their resources in the best possible way to diverse products and innovations (the main objective) as a competitive advantage in order to survive in the realm of competition. In addition, many of today's organizations in the world are moving towards increasing their business environment. Perhaps one of the reasons for this is the need to respond to multiple customer needs. Managers by meeting the multi-faceted needs of their customers, try to make them more loyal to their organization. For this and other technical reasons, such as the need to provision of raw materials and the distribution system of final product within the organization, many organizations have become diverse. In the second half of the twentieth century, due to the vulnerability of specialized companies against the rapid and unexpected changes in the environment, "diversification" became the basis for the growth and survival of the companies (Penroz, 1959).

Diversification is a kind of corporate strategy that many managers use to improve their company's performance. Companies vary in terms of activity and geographic diversification.

According to the definition of Ramaniou jamu and Varadarajan; diversity is the extent to which institutions simultaneously engage in various business activities (Raganatan, 1995).

There are three levels of diversification:

1- Diversification due to the close connection of products,

2. Diversification based on main competency,

3- Diversification in unrelated products (Lynch, 2006).

Diversification has advantages and disadvantages as well. Researchers have examined the benefits and costs associated with product diversity and its possible contributing factors. 
For various reasons, such as the economic horizon and increased market power (Marquids and Williamson, 1996), more efficient use of existing resources and capabilities (Barney, 1997), risk reduction and security protection against the uncertainty of the future (Lobatkin and Chatterjee, 1994), The creation of a domestic capital market (Rommel, 1982), an increase in debt capacity (Lolin, 1971). Organizations benefit from diversification.

On the other hand, diverse companies benefit from asset depreciation in various activities, disseminating product and technology throughout the process of different units and learning curve (Barney, 1997).

Diversification enables companies to benefit from economies of scale and diversified economy. Chandler (1969) states that diversification makes diverse companies benefit from cost savings from a managerial scale.

But diversification also has disadvantages, Braight (1969) states that companies that focus on a business line for a long time, could achieve more success. Focusing on a business line (in full or in a small amount of diversity) has many managerial and organizational benefits as follows:

A concentrated business has less ambiguity about "who we are" and "what we do."

1. The power of the whole organization will focuses on a unique business.

2. The time of senior executives or organizational resources is lesser wasted on a activity.

3. Entrepreneurship efforts focus exclusively on maintaining company's strategy and competitive approach.

4. Instead of pursuing short-term interests, managers are looking for ways to strengthen the long-term competitive position of firms in various industries.

5. The company uses all its organizational resources to improve its competitive skills.

6. When management focuses only on a business line, the likelihood of producing better ideas on how to improve technology will increase, which will better match the needs of customers with the features of the new product.

\section{Theoretical Foundations and Previous Research}

Many of today's organizations in the world are looking to expand and increase their business environments. Perhaps one of the reasons for this is the need to respond to multiple customer needs. Managers by meeting the multi-faceted needs of their customers, try to make them more loyal to their organization. For this and other technical reasons, such as the need to provision of raw materials and the distribution system of final product within the organization, many organizations have become diverse. In the second half of the twentieth century, due to the vulnerability of specialized companies against the rapid and unexpected changes in the environment, "diversity" became the basis for the growth and survival of the companies (Penroz, 1959).

Investors are always need adequate information to use in their decisions; especially decisions must generate financial value in the company. On the other hand, the search for the best index of company valuation is one of the most prominent features of the financial studies of the present era. Corporate executives are now facing a period that requires them to set up a new economic framework in their companies to reflect better value and profitability.

Many economists claim that managers of business enterprises must have a critria to appraise and evaluate their performance and help them to decide on choosing a way among various existing approaches.

We can use two criteria for performance evaluation. First, Financial accounting criteria (including return on assets, return on equity, dividends per share, stock returns), and second economic criteria (including economic value added, market value added, Adjusted economic value added).

\section{Experimental Background}

Fukuyou and Yoshi-Jimma (2007) examined the diversification of firms, performance and restructuring in the biggest Japanese companies, and stated that on average there is a negative relationship between the diversification and the company's performance.

Borger et al. (2010) investigated "the effect of focusing against diversification on the performance of banks," and their published results were as follows: diversification in four dimensions of loans, deposits, assets, and geography is resulted in reduced profits and increased costs.

Kang et al. (2011) examined the effect of diversification on company's performance and complementary products, and the result of the study indicated that: there is a U-shaped inverse relationship between product diversity, 
company's performance, and complementary products.

Anil and Yeghit (2011) examined the relationship between the diversification strategy and the organization's performance and their results indicated that: the relationship between diversification strategy and performance is influenced by factors such as working conditions, crisis, and lack of full competition conditions in the market.

Sue and Leon Lee (2012) investigated the impact of diversification on firm's performance and performance risk formulation, and their results stated that the effect of diversification on the performance of companies is not homogeneous at various levels.

Chin and Josephio (2012) conducted a study entitled "The Study of the Relationship between Management Ownership, diversification, and firm's Performance" and their results is as follows: There is a U-shape relation between management ownership and diversification in big firms.

Lucman et al. (2013) examined the impact of business diversification on the performance of the African construction companies and concluded that: There is a significant difference in the performance of diversified and non-diversified companies.

\section{Methodology}

This study is applicable in terms of purpose and is correlational in terms of the nature. This study has a deductive-inductive approach and is a regression analysis study among correlational studies type. In addition, given that the data used in the research is real and historical information, it can be categorized as a post-event type.

The statistical population of this study is all listed companies at Tehran Stock Exchange from 2008 to the end of 2015. The systematic elimination method has been used to determine the statistical sample. For this purpose, 263 companies have been selected to evaluate the models and test the research hypotheses. In addition, to formulate the theoretical foundations of the research, the library method is used and to collect the required data the information of the Central bank's portal and the financial statements provided to the Stock Exchange, as well as other relevant information sources such as Tadbir Pardaz and Rahavard Novin V03 has been used.

\section{Hypothesis}

Diversification influences the value of listed companies at Tehran Stock Exchange.

\section{Model and Variables}

In this research, after collecting observations, the following model is estimated to examine the relationship between corporate diversification and firm's value.

$$
\begin{aligned}
\text { ExcessValue }_{i t}= & \beta_{0}+\beta_{1} \text { TE }_{i t}+\beta_{2} \text { EBITSALE }_{i t}+\beta_{3} \text { CAPEXSALE }_{i t}+\beta_{4} \text { ISIZE }_{i t}+\beta_{5} \text { LEV }_{i t}+\beta_{6} \text { SG }_{i t}+\beta_{7} \text { FSIZE }_{i t} \\
& +\beta_{8} \text { FSIZE }_{i t}^{2}+\varepsilon_{i t}
\end{aligned}
$$

where $\mathrm{i}$ identifies each firm, $\mathrm{t}$ indicates the year of observation, and $\mathrm{p}$ are the coefficients to be estimated, and it is the random disturbance. The dependent variable is excess value (ExcessValue), TE is TotalEntropy. we control for profitability, level of current investment, financial leverage, firm size (and its square), industry (Industry dummies. Profitability is estimated by the EBIT to sales ratio (EBITsales), and the level of investment by capital expenditures to total sales ratio (CAPEXsales). Financial leverage is measured by the ratio of long-term debt to total assets (LDTA), and firm size is approximated by the natural logarithm of the book value of total assets (LTA) and Sales growth is computed as follows:

\section{dependent variable}

$$
\text { SalesGrowth }=\frac{S_{i t-} S_{i t-1}}{S_{i t-1}}
$$

The dependent variable is excess value (ExcessValue), and is defined as the natural $\log$ of a firm's market value to its imputed value.

\section{independent variable}

independent variable is proxied by TotalEntropy and TotalEntropy is computed as follows: 


$$
\text { TotalEntropy }=\sum_{S=1}^{n} P_{S} * \ln \left(\frac{1}{P_{S}}\right)
$$

where 'Ps' is the proportion of a firm's sales in segment 's' for a company with ' $n$ ' different 4-digit SIC segments. The higher the total entropy, the greater the diversification, although this index has no upper boundary.

\section{Findings of the Study}

\subsection{Descriptive Statistics of Research}

The descriptive statistics provide a general overview of the distribution of research data. Descriptive statistics for the sample companies are presented in Fig. 1.

Table 1. Summary Statistics of Variables for the Full Sample

\begin{tabular}{cccccc}
\hline variables & $\underline{\text { Mean }}$ & $\underline{\text { median }}$ & $\underline{\max }$ & $\underline{\min }$ & $\underline{\text { SD }}$ \\
\hline ExcessValue & $12 / 96$ & $12 / 97$ & $16 / 61$ & $10 / 16$ & $1 / 34$ \\
TE & $0 / 02$ & $0 / 01$ & $0 / 14$ & $0 / 00$ & $0 / 02$ \\
EBITSALE & $0 / 19$ & $0 / 16$ & $0 / 60$ & $-0 / 20$ & $0 / 15$ \\
CAPEXSALE & $0 / 03$ & $0 / 00$ & $1 / 52$ & $-0 / 71$ & $0 / 18$ \\
ISIZE & $16 / 78$ & $16 / 96$ & $18 / 68$ & $14 / 36$ & $0 / 92$ \\
LEV & $0 / 65$ & $0 / 66$ & $1 / 16$ & $0 / 24$ & $0 / 18$ \\
SG & $0 / 20$ & $0 / 18$ & $0 / 96$ & $-0 / 34$ & $0 / 24$ \\
FSIZE & $13 / 12$ & $13 / 01$ & $16 / 36$ & $10 / 59$ & $1 / 18$ \\
\hline
\end{tabular}

According to Figure 1, the results show that the average (middle) variables of the company's value is 12/96 (12/97), Firm's diversification 0/02 (0/01), EBITSALE 0/19 (0/16), CAPEXSALE 0/03 (0/00), ISIZE 16/78 (16/96), financial leverage $0 / 65$, Sales growth is $0.20(0.18)$ and the company size is $12 / 13(13.01)$. Also, the maximum (minimum) variables of the company's value were 16/61 (10/16), corporate diversification was 14/0 (0,00), profit-to-sales ratio was $60 / 0(-20,0)$, the ratio of capital expenditures to sales was $52 /(0.71)$, the size of the industry was $18.68(14.36)$, the financial leverage was $16.1(0.24)$, the sales growth was $0.96(-0.34)$ and the size of the company was $36 / 16(59 /$ 10).

\subsection{Examining the Correlation between Variables}

In this section, we investigate the relationship between research variables and the correlation between them, using the Pearson correlation coefficient. The matrix of correlation coefficients of the variables is presented in Fig. 2.

Table 2. Examining the Correlation between Variables

\begin{tabular}{cccccccc}
\hline variables & ExcessValue & TE & EBITSALE & CAPEXSALE & ISIZE & LEV & SG \\
\hline ExcessValue & 1 & & & & & & \\
TE & $0 / 26$ & 1 & & & & & \\
EBITSALE & $0 / 45$ & $0 / 07$ & 1 & & & & \\
c.sale & $0 / 08$ & $-0 / 03$ & $0 / 05$ & 1 & & \\
ISIZE & $0 / 43$ & $0 / 14$ & $0 / 28$ & $0 / 06$ & 1 & & \\
LEV & $-0 / 07$ & $0 / 00$ & $-0 / 20$ & $0 / 01$ & $-0 / 09$ & 1 & 1 \\
SG & $0 / 24$ & $0 / 02$ & $0 / 20$ & $-0 / 02$ & $0 / 20$ & $-0 / 01$ & $0 / 16$ \\
FSIZE & $0 / 71$ & $0 / 18$ & $0 / 02$ & $0 / 03$ & $0 / 22$ & $0 / 08$ & 1 \\
\hline
\end{tabular}

Based on the results of Pearson statistical test, there is a significant correlation between study's variables. 


\section{Results of Variables' Reliability Test}

In order to investigate the reliability of the research variables, the root tests of Im and colleagues, generalized Dickey Fuller, and the Phillips and Peron tests have been used and the results are presented in Table (3).

Table 3. Results of Variables' Reliability Test

\begin{tabular}{cccc}
\hline \multirow{2}{*}{ variables } & $\begin{array}{c}\underline{\mathrm{Im},} \\
\text { Pesaran }\end{array}$ & $\underline{\underline{\text { Augmented }}}$ & \\
& $\underline{\underline{\text { and Shin }}}$ & $\underline{\underline{\text { Dicky-Fuller }}}$ & \\
\hline ExcessValue & $-21 / 28$ & $1178 / 81$ & $1445 / 22$ \\
TE & $-42 / 63$ & $720 / 27$ & $803 / 17$ \\
EBITSALE & $-16 / 45$ & $976 / 26$ & $1088 / 98$ \\
CAPEXSALE & $-31 / 70$ & $411 / 35$ & $484 / 02$ \\
ISIZE & $-20 / 23$ & $552 / 96$ & $931 / 75$ \\
LEV & $-16 / 61$ & $806 / 48$ & $930 / 03$ \\
SG & $-32 / 44$ & $936 / 93$ & $1112 / 82$ \\
FSIZE & $-50 / 48$ & $1240 / 10$ & $1519 / 18$ \\
\hline
\end{tabular}

The results show that all research variables are reliable at 5\% and less, and using them in estimating research models does not lead to false results.

\section{Estimation of Research Models}

As mentioned, in this research hypotheses are estimated using regression approach and panel data method. In these models, the Hausman test has been used in order to determine whether the panel data method, or the combination data and the $\mathrm{F}$ test is effective in estimating the data, and to determine which method (fixed effects or random effects) is more suitable for estimation. The results of these tests are shown in Figure 4.

Table 4. Estimation of Research Models

\begin{tabular}{|c|c|c|c|}
\hline \multicolumn{4}{|l|}{ dependent variable: excess value } \\
\hline Variables & t-Statistic & P-value & $\underline{\mathrm{VIF}}$ \\
\hline Width from origin & $4 / 39$ & $(0 / 01)$ & --- \\
\hline $\mathrm{TE}$ & $0 / 05$ & $(0 / 00)$ & 1.07 \\
\hline EBITSALE & $3 / 22$ & $(0 / 00)$ & 1.18 \\
\hline CAPEXSALE & $0 / 32$ & $(0 / 00)$ & 1.02 \\
\hline ISIZE & $0 / 25$ & $(0 / 00)$ & 1.18 \\
\hline LEV & $-0 / 26$ & $(0 / 00)$ & 1.06 \\
\hline SG & $0 / 05$ & $(0 / 36)$ & 1.09 \\
\hline FSIZE & $-0 / 17$ & $(0 / 50)$ & 3.40 \\
\hline FSIZE^2 & $0 / 03$ & $(0 / 00)$ & 3.14 \\
\hline Adjusted R2 & $87 / \% 92$ & & \\
\hline (P - value) F-statistic & $(0 / 00)$ & 764.94 & \\
\hline Durbin-Watson stat & 1.67 & & \\
\hline $\mathrm{Chu}$ - test results & $(0 / 37)$ & 1.09 & \\
\hline Breusch-Pagan & $(0 / 92)$ & 0.01 & \\
\hline
\end{tabular}


The results of the model estimation show that the intercept (4.39) is significant at the $5 \%$ and the coefficient of the corporate diversification (0.05), the ratio of profit to sales (3.22), the ratio of capital expenditures to sales $(0.32)$, industry size $(0.25)$, financial leverage $(-0.26)$ and square of company size $(0.03)$ are significant at the $1 \%$ confidence level.

The value of the index of inflation factor variance also shows that the independent variables of the model do not have a severe coherence problem. The significance of the Fisher statistic (7464.9) at the level of $1 \%$ indicates that the overall model is significant. The value of the Durbin Watson statistic (1.67) indicates that there is no first-order serial correlation in the disturbance components of the estimated model, so the results of the estimated model are not false and it is reliable for testing the hypothesis.

The adjusted coefficient of determination also shows that independent variables account for about $88 \%$ of the variations of the dependent variable. The positive and significant coefficient of the corporate diversification variable $(0.05)$ in the model indicates there is a significant relationship between corporate diversification and firm's value, so by increasing corporate diversification, this relationship is increases. In any case, there is a significant relationship between corporate diversification and company value and the research hypothesis is not rejected.

\section{The Results of the First Hypothesis}

Results of the hypothesis tests indicated that there is a significant relationship between corporate diversification and firm's value, so by increasing corporate diversification, this relationship is increases. . This conclusion is consistent with the results of Lukem et al. (2013) study. However, it is not consistent with Fukuyu and Yoshijima (2007).

\section{Conclusion}

In this study, we examine the effect of diversification on the growth opportunity and the value of listed companies at Tehran Stock Exchange for an 8-year period. We measured the effect of diversification on firm's value using a multivariate linear regression model and tested the effects of diversification on firm's value using the developed model. The results of the research were consistent with theoretical foundations, but it is not expected that this result will always achieved. The firm's value is not only affected by the mentioned variables in this study, but it can be influenced by the economic, political, and social conditions of the community.

\section{References}

Anil, I., \& Yigit, I. (2011). The Relation Between Diversification Strategy and Organiziational Performance: A Research on Componies Registered to The Istanbul Stoch Exchange Market. Procedia Social and Behavioral Scienes, 24, 1494-1509. https://doi.org/10.1016/j.sbspro.2011.09.093

Baron, R., \& Kenny, D. (1986). The moderator-mediator variable distinction in socialpsychological research: conceptual, strategic and statistical considerations. Journal of Personality and Social Psychology, 51(6), 1173-1182. https://doi.org/10.1037/0022-3514.51.6.1173

Berger, A. H. (2010). The Effects of Focus Versus Diversification on Bank Performance: Evidence Chinese Banks. Journal of Banking \& Finance. Journal of Banking \& Finance, 34, 1417-1435. https://doi.org/10.1016/j.jbankfin.2010.01.010

Fukui, Y., \& Ushijima, T. (2007). Corporate Diversification, Performance, and Restructuring in the Largest Japonese Manfactorers. J.Japonese Int. Economies, 21(3), 303-330. https://doi.org/10.1016/j.jjie.2006.06.002

Kang, K. L. (2010). The Effects of Product Diversification on Firm Performance and Complemenarities Between Product. International Journal of Hospitality Managemebt, 30(2), 409-421. https://doi.org/10.1016/j.ijhm.2010.06.008

Lubatkin, M., \& Chatterjee, S. (1994). Extending modern portfolio theory into the domain of corporate diversification: Does it apply. Academy of Management Journal, 37, 109-136. https://doi.org/10.5465/256772

Lugman, Y., Abimbola, W., \& Keith, S. (2013). Impact of Business Diversification on South Africa Contraction Companies Corporate Performance . Journal of Financial Management of Peroperty and Construction, 18, 110-127. https://doi.org/10.1108/JFMPC-12-2012-0045

Lynch, R. (2006). Corporate Strategy. Financial Times(4th Ed.). 
Markides, C., \& Williamson, J. (1996). Corporate Diversification and Organizational Structure: A Resource-Based View. The Academy of Management Journal, 39(2), 340-367.

Penrose, E. (1959). The Theory of the Growth of the Firm. New Yor: Oxford university press.

Raghunathan, S. P. (1995). Refinement of the entropy measure of firm diversification: computational accuracy. Journal of Management, 21(5), 989-1002. https://doi.org/10.1177/014920639502100510

Tastan Boz, I., Yigit, I., \& Anil, I. (2013). The Relationship Between Diversification Strategy and Organizational Performance: A Research intented for Comparing Belgium and Turkey. Procedia - Social and Behavioral Sciences, 99, 997-1006. https://doi.org/10.1016/j.sbspro.2013.10.573 